\title{
Penerapan Teknologi Tepat Guna dan Diversifikasi Pangan pada UKM Olahan Ikan Bandeng di Desa Bulu Cindea Kecamatan Bungoro, Pangkep
}

\author{
Nur Fitriani Usdyana Attahmid ${ }^{1}$, Rahmawati Saleh ${ }^{2}$, Muhammad Yusuf ${ }^{3}$ \\ 1,2 Politeknik Pertanian Negeri Pangkep, ${ }^{3}$ Politeknik Negeri Ujung Pandang
}

\begin{tabular}{l} 
Article History \\
\hline Received 16.09.2019 \\
Received in revised form \\
29.11.2019 \\
Accepted 03.12.2019 \\
Available online 16.12 .2019
\end{tabular}

\section{ABSTRACT}

APPLYING APPROPRIATE TECHNOLOGY AND FOOD DIVERSIFICATION IN SMALL AND MEDIUM ENTERPRISES OF MILKFISH PROCESSING IN BULU CINDEA VILLAGE, BUNGORO DISTRICT, PANGKEP. Village of Bulu Cindea Bungoro District is a village located in Pangkep Regency. The village has the potential in developing milk fish based processed food products. The abundance of milkfish products in this area has a positive impact on the Small and Medium Enterprises in the milk processing industry. Milkfish is very popular with the community because it has a low price and has a specific taste. Every 100 grams of fresh milkfish contains: $129 \mathrm{kcal}$ energy, $76.85 \%$ water content, 20.38 gram fat content, $20.38 \mathrm{mg}$ protein content, $150 \mathrm{mg}$ phosphorus content, $2 \mathrm{mg}$ iron, vitamin A 150 SI, vitamin B1 : $0.05 \mathrm{mg}$, and also contains Omega-3 of $14.2 \%$. Milkfish has weaknesses, namely the presence of many thorn bones scattered throughout the meat section and the diversification of processed products is still simple with low product quality, packaging that is not hygenic, packaging identity that includes labeling and nutritional chemical composition has not been met and inadequate business licensing. Empowerment of Micro, Small and Medium Enterprises is the key to the development of small industries in Pangkep Regency, both in terms of quality and quantity, as well as its supporting factors. Through the Community Partnership Program activities, a number of activities to develop fresh milkfish processing business without thorns and shredded fish to Small and Medium Enterprises who are partners are UKM Alifa Mandiri, which is one of the platforms to empower food processing industry players. This activity is very important considering the diversification of processed milkfish processing technology without thorns and shredded fish is still done conventionally so that it requires appropriate technology and diversification of appropriate processing.

KEYWORDS: Appropriate Technology, Diversification, Food Processing, Milk Fish, Small and Medium Enterprises. 


\section{PENDAHULUAN}

Ikan bandeng (chanos chanos) adalah jenis ikan yang sangat popular di Asia Tenggara. Ikan ini merupakan satu-satunya spesies yang masih ada dalam family Chanidae. Dalam bahasa bugis dan makasar dikenal dengan sebutan ikan bolu dan dalam bahasa inggris milkfish. Ikan ini hidup di Samudera Hindia dan Samudera Pasifik dan cenderung berkawanan di sekitar pesisir dan pulau-pulau dengan terumbu koral. Ikan yang masih muda dan baru menetas akan hidup di laut sampai usia 2 sampai 3 minggu. Setelah itu ikan akan berpindah ke rawa-rawa bakau berair payau, dan kadang kala danau-danau berair asin. Bandeng baru kembali ke laut jika sudah dewasa dan siap berkembang biak. Ikan bandeng disukai sebagai makanan karena rasanya gurih, rasa daging netral (tidak asin) dan tidak mudah hancur jika dimasak. Kelemahan bandeng ada dua yaitu dagingnya berduri dan berbau lumpur/tanah. Duri bandeng sebenarnya adalah tulang dari bandeng. Duri ini mengganggu kenikmatan dalam memakan dagingnya. Bau lumpur pada bandeng banyak dialami pada bandeng yang diambil dari tambak. Bandeng yang dipelihara di karamba hampir tidak berbau. Penyebab gejala bau lumpur adalah beberapa plankton Cyanobacteria, terutama dari genus Oscillatoria, Symloca, dan Lyngbia, yang menghasilkan geosmin. Apabila ikan tinggal di tempat yang kaya geosmin atau memakan plankton ini, dagingnya akan memiliki cita rasa tanah (Wibowo, Suryaningrum, \& Utomo, 2017).

Ikan bandeng merupakan salah satu jenis ikan yang memiliki kandungan gizi yang sangat tinggi, dimana ikan ini sangat kaya akan protein-protein hewani yang sangat dibutuhkan bagi tubuh manusia. Perkembangan ikan bandeng sampai saat ini telah mengalami kemajuan yang sangat pesat, mulai dari kalangan masyarakat golongan menengah kebawah sampai dengan golongan masyarakat menengah ke atas sangat gemar untuk mengkonsumsi ikan jenis ini. Tingginya tingkat konsumsi terhadap ikan bandeng saat ini dikarenakan olahan ikan bandeng yang kini ada di masyarakat sangat beragam dan memiliki rasa serta manfaat yang sangat tinggi. Ikan bandeng merupakan salah satu jenis ikan olahan konsumsi yang membutuhkan keahlian dan tahapan khusus untuk menghasilkan olahan makanan yang berkualitas. Struktur daging yang tidak seperti ikan pada umumnya menjadikan ikan jenis ini perlu tahapan khusus pengolahan tersebut. Kandungan daging ikan bandenga dengan kombinasi tuang duri ikan yang sangat banyak menjadikan ikan ini susah untuk diolah namun dengan pengetahuan yang memadai atas jenis ikan ini menjadikan pengolahan ikan bandeng sangat menarik.

Ikan bandeng dilihat dari segi komposisi kimia dan nilai gizinya menunjukkan bahwa ikan bandeng mempunyai arti yang penting. Dalam daging ikan bandeng cukup mengandung vitamin dan protein. Menurut (Vatria, 2010), ikan bandeng memiliki daging yang praktis dikonsumsi (tidak ada duri), jenis olahan ini juga mempunyai kandungan yang kaya akan Omega-3 yang dapat menyembuhkan penyakit penyempitan pembeluh darah dan tulang. Disamping itu juga DHA berperan untuk pertumbuhan sel otak anakanak sehingga sangat bagus bagi pertumbuhan dan perkembangan anak-anak. Senyawa DHA berperan dalam membangun 14 juta sel otak (70\% massa otak terdiri dari lemak) pada masa kritis yaitu sebelum kelahiran atau selama kehamilan sampai 18 bulan pertumbuhan dan perkembangan anak, selain itu ikan bandeng memiliki kandungan kolesterol yang rendah, sehingga tidak dapat diedarkan langsung oleh darah karena tidak larut dalam air. Untuk mengedarkannya, diperlukan molekul "pengangkut" yang disebut 
lipoprotein. Ada dua jenis lipoprotein, yaitu high density lippoprotein (HDL) dan low density lippoprotein (LDL) (Fitriani \& Yusuf, 2016). Oleh karena itu pada masa kritis akan sangat baik bila gizi ibu dan bayi dicukupi dengan gizi mikro dan makro, termasuk asam lemak esensial omega-3 dan omega-6 (Zulaihah \& Widajanti, 2012). Tingkat umur simpan ikan bandeng olahan yang sangat rendah ini menjadikan penjualan ikan bandeng konsumsi hanya sebatas waktu dan tempat tertentu saja. Dengan umur simpan yang sangat rendah menjadikan penjualan olahan ikan bandeng ini sangat terbatas dan sampai saat ini hanya dengan batasan yang sangat rendah. Kondisi ini sangat perlu diatasi untuk meningkatkan nilai ekonomi dan nilai jual olahan ikan bandeng.

Salah satu Usaha Kecil dan Menengah (UKM) di Desa Bulu Cindea, Kecamatan Bungoro Kabupaten Pangkep yang telah berhasil membentuk dan mengolah produk olahan ikan bandeng yang cukup aktif adalah UKM Alifa Mandiri binaan Ibu Risnawati. Organisasi ini digerakkan oleh masyarakat yang berprofesi sebagai nelayan dan petambak. Kelompok ini juga sangat kooperatif dan memiliki minat tinggi untuk melaksanakan kegiatan yang dapat mengangkat kesejahteraan keluarga. UKM ini merupakan salah satu kelompok usaha di Kabupaten Pangkep dengan kegiatan ekonomi utama berupa produk olahan yang menggunakan bahan baku utama ikan bandeng. Produk-produk yang dihasilkan cukup bervariasi, seperti bandeng tanpa duri, abon ikan bandeng, dan ikan bandeng segar. Jumlah anggota UKM ini mencapai 20 (dua puluh) orang, akan tetapi yang aktif memproduksi berbagai produk olahan ada sekitar 10 orang. Pembuatan dan proses produksi dilakukan 3 kali seminggu, yaitu hari Senin, Rabu dan Sabtu. Secara keseluruhan perminggu untuk memproduksi olahan ikan bandeng diperlukan bahan baku sekitar $25 \mathrm{~kg}$ daging ikan bandeng. Penjualan dan pemasaran produk dilakukan dengan cara menitipkan pada toko, koperasi kantor, pesanan ataupun penjualan secara langsung.

Politeknik Pertanian Negeri Pangkep (PPNP) sebagai salah satu perguruan tinggi yang menyelenggarakan Program Pengabdian kepada Masyarakat telah menawarkan salah satu program kegiatan, yakni Program Kemitaan Masyarakat (PKM). Jurusan Teknologi Pengolahan Hasil Perikanan, Program Studi (Prodi) D4 Agroindustri sebagai salah satu unit pelaksana pendidikan, penelitian, dan pengabdian kepada masyarakat memiliki sumber daya manusia, yakni dosen dan mahasiswa yang mampu berperan sebagai agen yang mentransformasikan ilmu maupun teknologi kepada masyarakat. Sinergi yang dapat dibangun antara dosen, mahasiswa dan masyarakat Desa Tallung Tondok sangat diperlukan dalam mengoptimalkan potensi sumber daya alam maupun manusia yang ada di wilayah tersebut. Program implementasi Ipteks Bagi Masyarakat melalui pendampingan usaha kecil dan menengah (UKM) oleh Tim dari Prodi Agroindustri PPNP bertujuan untuk meningkatkan produktivitas potensi lokal, khususnya ikan bandeng yang ada di Desa Bulu Cindea, Kecamatan Bungoro Kabupaten Pangkep. Program tersebut dilakukan melalui aplikasi diversifikasi pangan berupa pembuatan produk amplang dan abon ikan bandeng, penyuluhan sanitasi dan hygiene proses produksi, penyuluhan P-IRT dan sertifikasi halal, analisis kimia gizi produk dan umur simpan (expire date), transfer teknologi peralatan, serta aplikasi pelabelan dan kemasan pangan (Kurniasih, 2018). Manfaat yang diharapkan dari program ini adalah diperolehnya informasi dan transformasi tentang aplikasi diversifikasi pangan dan kemasan dalam kehidupan sehari-hari sehingga dapat meningkatkan kesejahteraan masyarakat yang bersangkutan. 


\section{METODE PELAKSANAAN}

\section{Tempat dan Waktu}

Kelompok sasaran atau mitra pada kegiatan ini adalah Usaha Kecil dan Menengah (UKM) Alifa Mandiri Binaan Ibu Risnawati di Desa Bulu Cindea, Kecamatan Bungoro Kabupaten Pangkep. Kegiatan dilaksanakan mulai bulan April sampai dengan Oktober 2019.

\section{Partisipasi Kegiatan}

Pada kegiatan pengabdian ini, pihak-pihak yang terlibat selain dengan mitra, masyarakat sekitar, kelompok/pelaku usaha dan Petugas Penyuluh Lapangan (PPL) Kelurahan/ Kecamatan Kabupaten Pangkep.

\section{Metode Penyelesaian Masalah}

Upaya yang dilakukan dalam rangka meningkatkan pengetahuan dan ketrampilan dilakukan melalui diskusi, demonstrasi dan pembinaan. Pendekatan dilakukan melalui beberapa tahap, mulai tahap persiapan, pengurusan administrasi dan surat menyurat, tahap pendekatan personal dan kelompok sasaran, pelatihan dan demonstrasi.

\section{Pendekatan Kegiatan}

Metode pelaksanaan PKM di Kecamatan Bungoro dilakukan dengan metode partisipatif dan kooperatif. Pendekatan ini dilakukan agar kelompok sasaran dapat saling bekerja sama dan saling berdiskusi sesame kelompok sasaran sedangkan tim pelaksana berperan sebagai fasilitator selama proses diskusi berlangsung. Rangkaian kegiatan yang akan dilakukan selama kegiatan berlangsung dibuat secara bertahap yang meliputi :

1) Survei pendahuluan dan identifikasi permasalahan;

2) Kegiatan Diskusi;

3) Kegiatan pelatihan;

4) Kegiatan pembinaan;

5) Kegiatan Monitoring dan Evaluasi.

\section{HASIL DAN PEMBAHASAN}

\section{Profil Usaha Kecil dan Menengah (UKM) Alifa Mandiri}

Mitra kegiatan ini yaitu UKM Pengolahan Ikan di Kabupaten Pangkep yang dikelola oleh Ibu Risnawati yang bernama Kelompok Usaha Alifa Mandiri yang letaknya berada di Desa Bulu Cindea, Kecamatan Bungoro, Kabupaten Pangkep, Propinsi Sulawesi Selatan, yang memulai usaha sudah 4 tahun. Usaha ini mengolah $20 \mathrm{~kg}$ ikan bandeng segar setiap harinya yang dibantu oleh 6 orang tenaga kerja. Produk yang diolah berupa ikan bandeng segar tanpa duri, ikan bandeng presto dan abon ikan bandeng dengan kisaran harga Rp.10.000 - 25.000/produk. Adapun permasalahan yang dihadapi adalah 
peralatan yang digunakan dalam proses pengolahan ikan bandeng segar tanpa duri dan abon ikan masih sangat sederhana sehingga mutu produk yang dihasilkan berkualitas rendah. ikan bandeng segar tanpa duri dan abon ikan yang diproduksi memiliki kadar air yang cukup tinggi, sehingga produk cepat mengalami kerusakan. Perubahan mutu selama proses pengolahan misalnya warna, tekstur, aroma dan citarasa sangat mempengaruhi kualitas produk yang dihasilkan (Dewi \& Ibrahim, 2008).

Salah satu cara mempertahankan kualitas adalah tanpa mengubah warna, aroma khas dan rasa dari produk adalah dengan menggunakan alat penggoreng dan pengering yang lebih konvensional. Kapasitas produksi yang rendah juga menjadi permasalahan karena peralatan yang sederhana. Mutu produk yang rendah berakibat penurunan umur simpan produk yang sangat cepat, sehingga semua hal yang menjadi kelemahan diatas berimplikasi pada margin keuntungan yang rendah (Budijanto, Sitanggang, Silalahi, \& Murdiati, 2010). Selain itu, produksi yang rendah berkaitan dengan penggunaan kemasan yang sederhana, kadar air yang tinggi dan penggunaan peralatan yang masih sederhana dan bergantung pada lingkungan untuk pengeringan ikan bandeng. Masalah lain yakni belum diterapkannya sanitasi dan hygiene dalam proses penanganan bahan baku, pengolahan pangan dan kebersihan pekerja. Produk ikan bandeng segar tanpa duri dan abon ikan masih dikemas secara sederhana menggunakan plastik polietilen (PE) yang mudah ditembus oleh udara sehingga produk lebih cepat berjamur karena memiliki kadar air yang tinggi, hal ini berdampak pada umur simpan atau masa kadaluarsa produk yang hanya 3 minggu saja. Diperlukan kemasan cerdas yang merupakan kemasan yang mampu memberikan informasi kesegaran dari produk makanan yang dikemasnya, karena dapat memantau kualitas dan keamanan produk pangan selama penyimpanan, transportasi dan pemasaran. Pengemasan cerdas bertujuan untuk mengawasi kondisi makanan terkemas untuk mendapatkan informasi mengenai kualitas makanan dalam kemasan secara "real time" ( Yusuf, Indriati, Usdyana, \& Rosalin, 2019))

Selain dari segi peningkatan kapasitas produksi, hal lain yang perlu dilakukan adalah perluasan area pemasaran. Selama ini pemasaran hanya dilakukan secara tradisional dan terbatas pada area disekitar daerah produksi, sehingga dibutuhkan inovasi dalam hal pengemasan produk yang lebih menarik dari segi fungsinya untuk melindungi produk dan dapat menonjolkan informasi yang dibutuhkan oleh konsumen dalam hal masa kadaluarsa, kehalalan produk, komposisi gizi, penggunaan bahan dll. Sejalan dengan program pemerintah Kabupaten Pangkep untuk memunculkan brend Market Pangkep sebagai penghasil ikan bandeng dengan berbagai produk olahan unggulan, maka program PKM DIKTI diharapkan dapat membantu mencapai sasaran dalam bentuk penerapan teknolgi pada proses pengolahan berbagai produk tersebut. Produk unggulan yang direncanakan adalah bandeng cabut duri, bandeng abon, dan nuget ikan bandeng dalam kemasan.

Hasil yang Dicapai dari Kegiatan ini adalah sebagai berikut :

1) Peningkatan pengetahuan mitra melalui penyuluhan partisipatif mengenai teknologi pengolahan abon dan amplang ikan bandeng dengan teknik yang tepat sehingga mampu meningkatkan mutu dan efisiensi pengolahan bahan baku menjadi produk pangan dalam meningkatkan nilai ekonomis dan pendapatan masyarakat. 
2) Alih Teknologi dan pengetahuan mengenai penerapan teknologi tepat guna dalam proses pembuatan olahan ikan bandeng, sehingga diperoleh produk yang lebih sehat, hygienis dan bergizi.

3) Alih Teknologi dan pengetahuan mengenai penerapan teknologi tepat guna rancangan alat peniris minyak dan pengemasan vakum untuk meningkatkan kualitas dan mutu produk pangan.

4) Pengetahuan yang diberikan meliputi teknik pemilihan bahan, pencucian, sterilisasi bahan kemasan, proses pengolahan bahan hingga menjadi makanan olahan, sampai pengemasan produk serta perizinan P-IRT dan sertifikasi halal MUI.

5) Pelatihan dilakukan sebagai sarana dan bahan pembelajaran mitra dengan pelibatan penuh mitra. Pada pelatihan ini, kelompok tani memperoleh pengetahuan teknik pengolahan ikan bandeng.

Target yang dicapai dari kegiatan ini adalah:

1) Melalui penyululuhan dan diskusi, mitra telah menyadari dan memahami mengenai pentingnya sanitasi dan hygiene dalam setiap tahapan proses produksi.

2) Bertambahnya pengetahuan mitra mengenai teknologi pengolahan bahan makanan dengan teknologi tepat guna sehingga mampu meningkatkan mutu dan efisiensi pengolahan bahan baku menjadi produk olahan ikan bandeng dalam meningkatkan nilai ekonomis dan pendapatan masyarakat.

3) Bertambahnya pengetahuan dan keterampilan mitra tentang kewirausahaan melalui pelatihan kewirausahaan pemasaran dan pengemasan yang diberikan.

4) Mitra mulai memproduksi produk olahan ikan bandeng dengan kemasan produk yang berkualitas.

5) Terciptanya lapangan kerja baru sehingga terjadi subtitusi kegiatan ekonomi masyarakat menjadi masyarakat yang mengolah bahan baku ikan bandeng menjadi produk olahan.

\section{Diverifikasi Olahan Ikan Bandeng}

Kegiatan penyuluhan dan pemberian contoh produk melalui demonstrasi serta pelatihan pembuatan abon dan kemplang ikan bandeng dengan aplikasi teknologi pangan tepat guna untuk menghasilkan produk yang bernilai jual tinggi, disukai konsumen, dan memiliki umur simpan yang panjang. Mitra hanya menjual produk ikan bandeng tanpa tulang saja. Aplikasi teknologi tepat guna yang disertai dengan perlakuan optimasi proses yang menghasilkan produk yang tidak hanya memperpanjang umur simpan dari produk, tetapi juga meningkatkan minat konsumen. Untuk menjadikan produk yang bernilai jual tinggi, maka dibutuhkan pengetahuan tentang diversifikasi produk olahan sehingga dapat menjadi nilai tambah bagi mitra. 


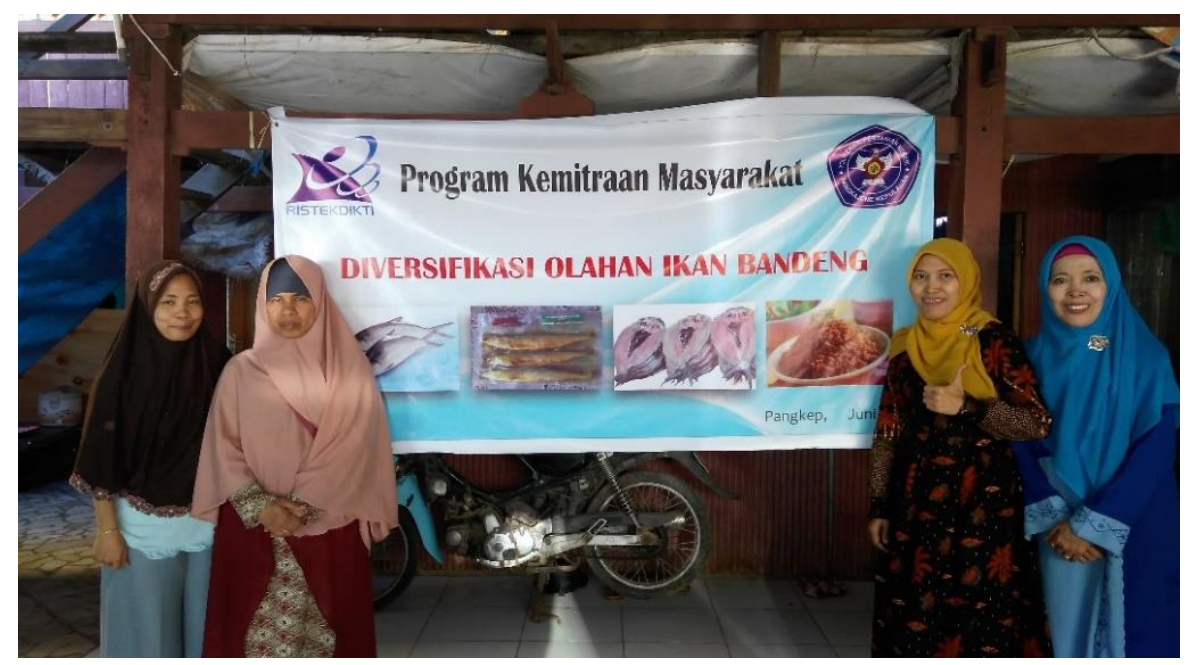

Gambar 1. Kegiatan Diversifikasi Olahan Ikan Bandeng Di Desa Bulu Cindea, Kecamatan Bungoro, Kabupaten Pangkep

\section{Penyuluhan Sanitasi dan Hygiene Proses Produksi}

Kegiatan penyuluhan tentang aspek pengelolaan produksi yang meliputi sanitasi dan hygiene serta cara pengolahan pangan yang baik dan benar dengan mengikuti kaidah GMP (Good Manufacturing Practices). Salah satu cara agar UKM yang menjual produknya mampu bersaing dengan industri rumah tangga yang lebih besar dan bergerak di bidang pangan adalah dengan meningkatkan kepercayaan konsumen dengan menumbuhkan kesadaran produsen dan karyawan tentang pentingnya proses produksi pangan yang higienis dan responsible terhadap keselamatan konsumen. Pemerintah melalui Badan Pengawas Obat dan Makanan menetapkan suatu pedoman atau peraturan tentang Cara Produksi Pangan yang Baik untuk Industri Rumah Tangga (CPPBIRT) atau biasanya disebut Good Manufacturing Practices (GMP) agar kualitas produk pangan yang dihasilkan tidak hanya mempunyai nilai gizi lagi, tetapi juga aman dan layak dikonsumsi. GMP merupakan pedoman cara berproduksi pangan yang bertujuan supaya produsen pangan memenuhi persyaratan-persyaratan yang telah ditentukan untuk menghasilkan produk pangan yang bermutu dan aman dikonsumsi sesuai dengan tuntutan konsumen. GMP wajib diterapkan oleh industri yang menghasilkan produk pangan sebagai upaya preventif agar pangan yang siap dikonsumsi tersebut bersifat aman, layak, dan berkualitas (Yusuf, Rosalin, \& Usdyana, 2018).

Desain dan fasilitas ruang produksi dapat digambarkan ruang produksi yang tidak di ruangan tertutup, kotor, memungkinkan serangan binatang pengerat, dan jauh dari kondisi higiene dan sanitasi yang baik. Kondisi lantai yang masih berbahan tanah dapat menjadi sumber kontaminasi untuk bahan baku, karena debu dan tanah adalah sumber penularan mikroba beserta sporanya (Yulia, 2016). Sedangkan pengamatan terhadap karyawan yakni Semua karyawan tidak pernah mencuci tangan sebelum mengolah. Semua karyawan tidak merokok saat bekerja. Semua karyawan tidak meludah saat bekerja. Semua karyawan tidak bersin dan batuk saat bekerja. Menyadari hal tersebut, kami bersama Kelompok Nelayan Biringkassi Bahari Mandiri melakukan penyuluhan dan bimbingan tentang tata cara pengolahan yang sesuai dengan prinsip GMP. Bertempat disalahsatu rumah anggota KWT, kami melaksanakan penyuluhan, dimana antusias 
kedua mitra sangat baik dalam menyimak materi dan diharapkan nantinya dapat di impelementasikan dalam proses pengolahan pangan.

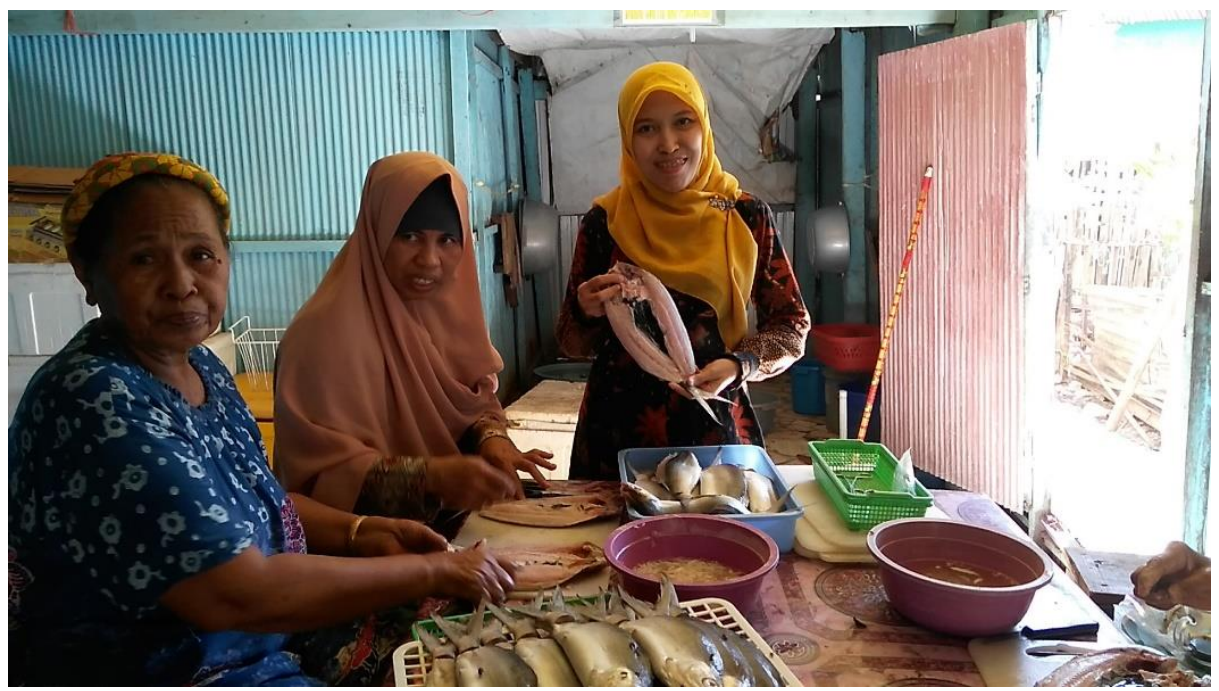

Gambar 2. Kegiatan Penyuluhan Tentang Sanitasi dan Hygiene serta Penerapan Good Manufacturing Practices (GMP) dalam Pengolahan Pangan

\section{Penyuluhan Kemasan dan Pelabelan Produk}

Kegiatan penyuluhan tentang aspek manajemen produksi yang meliputi penggunaan kemasan untuk pangan dan teknik pelabelan kemasan yang menarik bagi konsumen. Salah satu hal yang tidak dapat dilepaskan dari perkembangan makanan dan minuman adalah perkembangan kemasan yang digunakan untuk mengemas produk pangan tersebut. Kemasan disini adalah kemasan yang 'seharusnya' adalah kemasan yang aman bagi produk pangannya maupun bagi konsumen. Kemasan yang khusus digunakan untuk mengemas produk pangan sering disebut dengan kemasan pangan atau dikenal dengan istilah 'foodgrade'. Penggunaan kemasan oleh mitra untuk mengemas abon ikan dan bandeng tanpa duri menggunakan jenis kemasan polietilen yang kurang baik untuk mengemas bahan pangan yang berlemak, karena menyebabkan produk cepat mengalami kerusakan.

Mitra UKM Alifa Mandiri disarankan menggunakan kemasan berbahan dasar aluminium foil dan kemasan jenis polietilen LDPE (Low Density Polietilen) sangat tepat digunakan untuk mengemas abon ikan bandeng, karena memiliki daya simpan yang tahan lama, kuat dan tidak mudah sobek, resisten terhadap penetrasi lemak dan minyak serta mudah di klim panas. Sedangkan Ikan bandeng tanpa duri sebaiknya menggunakan kemasan full laminasi Polipropilen (PP). Menurut Erlena, Ma'ruf, dan Sumardianto, (2013), sifat-sifat kimia dari kemasan ini antara lain : (1) sukar ditembus oleh uap air, (2) tahan terhadap minyak dan lemak, (3) permeabilitas terhadap uap air rendah, (4) stabil pada suhu tinggi, dan mempunyai permukaan yang mengkilat. Polipropilen banyak digunakan sebagai pembungkus daging dengan proses pengemasan vacuum dan gas. Berdasarkan sifat-sifat tersebut maka digunakan polipropilen untuk mengemas produk sebagai kemasan primer dan menggunakan karton sebagai kemasan sekunder. Kegiatan penyuluhan dan bimbingan teknis tentang contoh jenis-jenis kemasan yang sesuai dengan 
produk melalui demonstrasi cara pengemasan yang baik dan tepat serta pemberian contoh alat kemasan yang sesuai.

\section{Introduksi Peralatan Teknologi Tepat Guna (TTG)}

Kegiatan pelatihan, introduksi dan pengoperasian teknologi tepat guna berupa alat pengemasan vakum dan peniris minyak. Rancangan alat peniris minyak diperlukan bagi UKM karena produk yang dihasilkan adalah abon ikan bandeng. Fungsi alat ini untuk mengeluarkan sebagian besar minyak dan air yang terdapat dalam abon ikan sehingga produk memiliki umur simpan yang relatif lebih lama serta dapat menghindari dari ketengikan. Pengenalan alat pengemasan vakum diperlukan untuk mengemas produk ikan bandeng tanpa duri dan abon ikan yang dalam bentuk kemasan aluminium foil terlaminasi.

Mesin spinner merupakan alat peniris minyak goreng yang memiliki kinerja yang efisien, alat yang satu ini dilengkapi dengan teknologi yang tepat guna yang dapat mengurangi kadar minyak yang terkandung didalam makanan dengan mudah, praktis dan cepat. Mesin dapat meniriskan minyak goreng pada produk makanan dengan lebih mudah, cepat dan praktis, adapun produk yang dihasilkan sangat memuaskan.Dimana bahan atau produk makanan yang dihasilkan menjadi lebih bersih dan kering dari minyak ataupun air. Selain digunakan untuk meniriskan produk makanan yang digoreng spinner juga berfungsi sebagai peniris air yang membuat produk makanan menjadi lebih cepat kering. Mesin tersedia dalam model yang beragam, masing-masing memilki spesifikasi dan harga yang berbeda-beda sehingga dapat disesuaikan dengan kebutuhan. Kemampuan mesin yang dapat mengurangi kadar minyak maupun air pada makanan membuat produk tersebut memiliki daya tahan yang jauh lebih lama. Mesin spinner menjadi solusi yang tepat untuk meniriskan makanan berminyak maupun produk yang mengandung air dengan cepat. Alat ini dapat berputar dengan tingkat kecepatan tinggi sehingga menjadikan kadar minyak pada produk makanan dapat berkurang dengan signifikan, namun tanpa mengurangi kualitas dan mutu dari produk makanan tersebut. Baik cita rasa, warna sampai teksturnya masih terjaga dengan baik. Mesin spinner bekerja dengan cara mengeluarkan air dan minyak dari makanan menggunakan prinsip sentrifugal. Makanan yang akan ditiriskan akan diletakkan dalam keranjang berlubang kecil yang telah disediakan. Keranjang tersebut akan diputar menggunakan tenaga listrik.

Fungsi alat pengemasan vakum untuk mengeluarkan $\mathrm{CO}_{2}$ yang ada didalam kemasan sehingga kontak antara udara dan bahan pangan lebih sedikit sehingga memungkinkan untuk mencegah kerusakan dan meningkatkan umur simpan produk. Pengemasan vakum juga diperlukan apabila produk-produk yang ada dipesan oleh konsumen di luar Sulawesi Selatan yang membutuhkan waktu transportasi lebih lama untuk diterima dan dikonsumsi oleh konsumen. Tidak rapinya packaging akan membuat udara, bakteri, kuman, dan hewan kecil mudah masuk dan merusak makanan. Meskipun telah dilengkapi dengan bungkus serta ditaruh dalam box tertutup tetapi tidak menjamin produk akan terkontaminasi. Masalahnya udara di sekitar ruangan akan memicu timbulnya resiko pada makanan, misalnya saja tumbuh jamur. Hal ini tentu saja akan membuat usaha Anda cepat merugi dan konsumen merasa kecewa. Tak hanya dipakai para pengusaha makanan saja tetapi masyarakat juga bisa memakai mesin yang satu ini. Salah satu resiko terbesar pengusaha produk makanan ataupun minuman adalah mudah kadaluarsa karena terkontaminasi. Oleh sebab itulah mengapa Anda sangat memerlukan 
mesin vacuum packaging ketika melakukan pengemasan. Akan sangat berbahaya sekali apabila hal ini sampai diabaikan karena dapat mempengaruhi kualitas dan kondisi dagangan. Mesin vacuum packaging merupakan alat pengemas barang yang mampu menghilangkan udara sebelum proses penyegelan. Prinsip kerjanya termasuk unik yaitu dengan cara menyedot udara atau oksiden di dalam wadah atau plastik kemasan sampai habis. Setelah itu, mesin akan melakukan penyegelan secara otomatis agar tidak ada lagi udara yang masuk ke dalam. Proses tersebut disebut sebagai sealing dengan cara dipanaskan dan ditekan agar kemasan menempel dan tak mudah terlepas. Dalam kemasan yang hampa udara maka produk makanan maupun minuman dapat terjaga dengan baik. Pengurangan oksigen akan mencegah terjadinya penguapan berlebih yang dapat mengakibatkan makanan lembab. Hal tersebut akan memicu timbulnya jamur dan bakteri lain, sehingga menjadi cepat kadaluarsa.

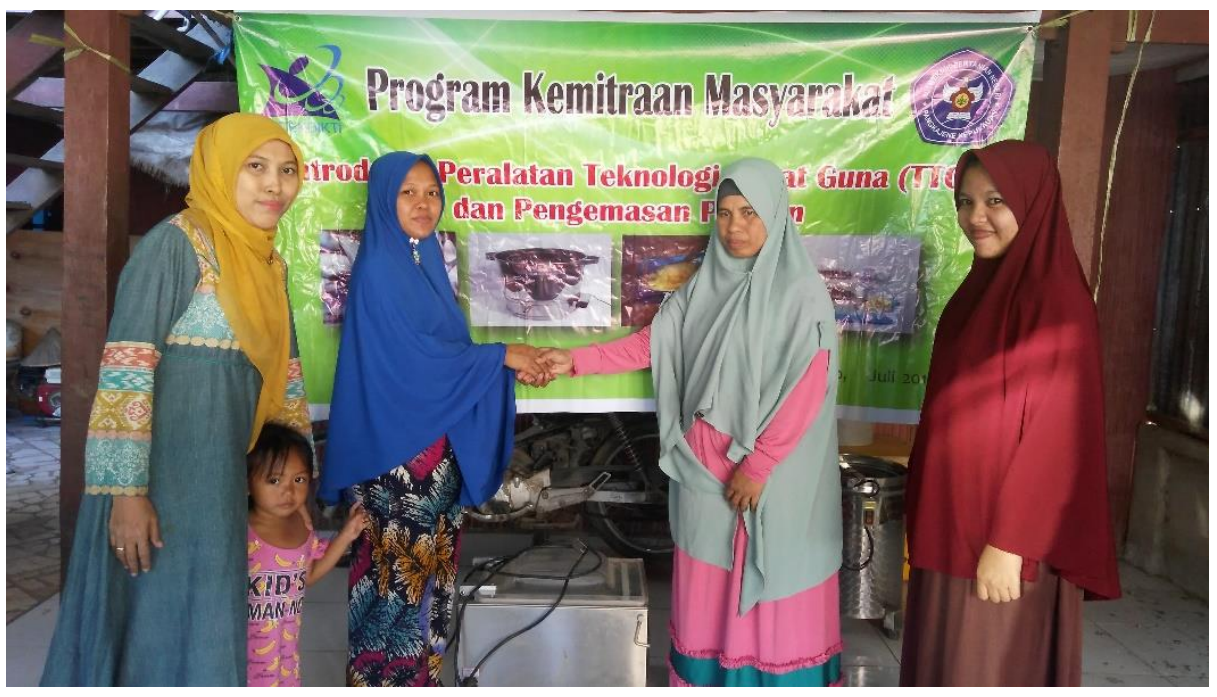

Gambar 3. Introduksi Peralatan dan Serah Terima Alat Pengemasan Vakum

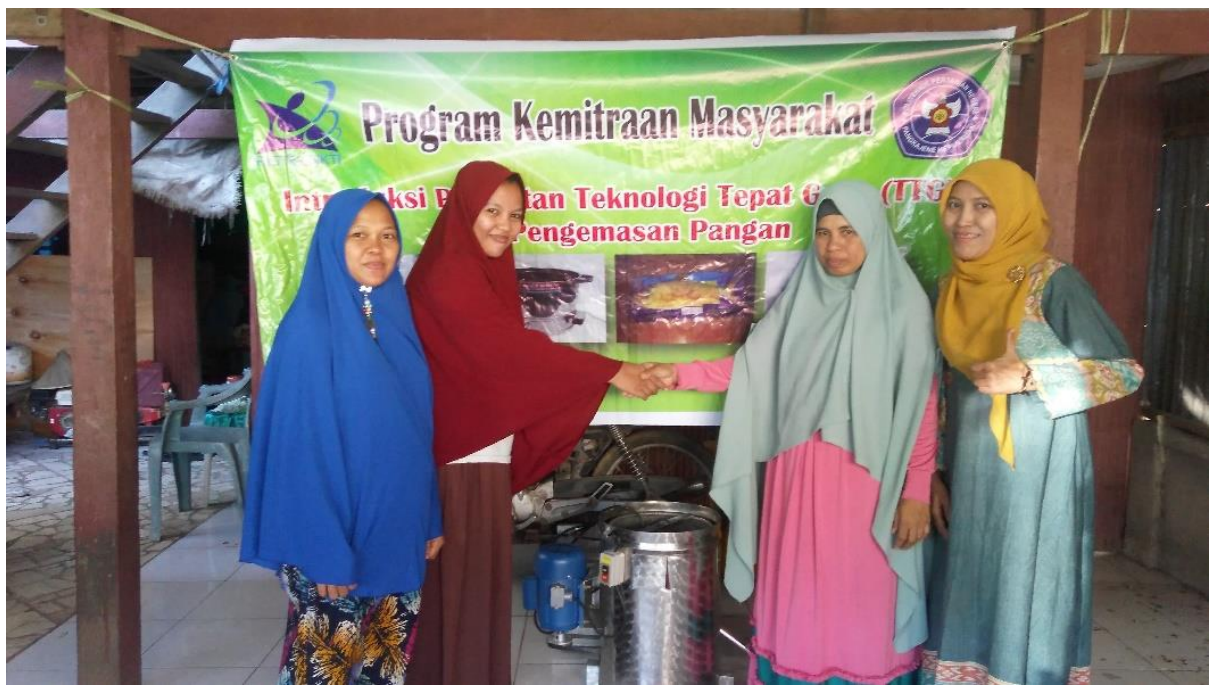

Gambar 4. Introduksi Peralatan dan Serah Terima Alat Peniris Minyak (Spinner) 


\section{SIMPULAN}

Simpulan dari kegiatan ini adalah bahwa keseluruhan tahapan kegiatan PKM (Program Kemitraan Masyarakat) Olahan Ikan Bandeng menghasilkan luaran yang telah ditargetkan. Penerapan teknologi tepat guna, teknologi pengolahan dan pengemasan serta sanitasi dan hygiene telah dilaksanakan oleh mitra UKM Alifa Mandiri. Mitra sangat antusias memproduksi produk olahan ikan bandeng yang bermutu dan berkualitas sehingga dapat meningkatkan ekonomi secara mandiri dan menjadikan produk olahan ikan bandeng sebagai produk lokal kebanggaan Kabupaten Pangkep, Sulawesi Selatan.

\section{REFERENSI}

Budijanto, S. A., Sitanggang, B., Silalahi, B. E., \& Murdiati, W. (2010). Penentuan umur simpan seasoning menggunakan metode accelerated shelf life testing (ASLT) dengan pendekatan kadar air kritis. Jurnal Teknologi Pertanian, 11(2), 71-77.

Dewi, N. E., \& Ibrahim R. (2008). Mutu dan daya simpan filet dendeng ikan nila merah yang dikemas hampa udara dengan vacuum sealer skala rumah tangga. Jurnal Saintek Perikanan, 4, 7-15.

Erlena, Y., Ma'ruf, W. F., \& Sumardianto. (2013). Aplikasi alginat sebagai emulsifier dalam pembuatan sosis ikan bandeng (Chanos chanos) pada penyimpanan kemasan vakum suhu ruang. Jurnal Pengolahan dan Bioteknologi Hasil Perikanan, 2(2), 134-145.

Fitriani, N., \& Yusuf, M. (2016). Penentuan high density lipoprotein (hdl) pada beberapa jenis ikan. Jurnal Galung Tropika, 5(1), 34-40.

Kurniasih, R. A. (2018). Karakteristik kimia, fisik, dan sensori ikan bandeng presto dengan lama pemasakan yang berbeda. Jurnal Ilmu Pangan dan Hasil Pertanian, 1(2), 13-20. https://doi.org/10.26877/jiphp.v1i2.1816

Vatria, B. (2010). Pengolahan ikan bandeng (Chanos-chanos) tanpa duri. Jurnal Ilmu Pengetahuan dan Rekayasa, 19-23.

Wibowo, S., Suryaningrum, T. D., \& Utomo, B. S. B. (2017). Kajian sifat fisiologi kerapu lumpur (epinephelus tauvina) sebagai dasar dalam pengembangan teknik transportasi hidup. Jurnal Penelitian Perikanan Indonesia, 8(6), 1-9. https://doi.org/10.15578/jppi.8.6.2002.1-9

Yulia. (2016). Higiene sanitasi makanan, minuman dan sarana sanitasi terhadap angka kuman peralatan makan dan minum pada kantin. Jurnal Vokasi Kesehatan, 2(1), 55-61.

Yusuf, M., Rosalin, R., \& Usdyana, N. F. (2018). Pemberdayaan kelompok wanita tani melalui diversifikasi pangan di Kecamatan Buntu Batu Kabupaten Enrekang. Jurnal Dedikasi Masyarakat, 1(2), 98-108. 
Yusuf, M., Indriati, S., Usdyana, N. F., \& Rosalin. (2019). Application selective media of microorganisms for smart packaging indicator in food materials. Jurnal Ilmiah Inovasi, 19(2), 76-82.

Zulaihah, S., \& Widajanti, L. (2006). Hubungan kecukupan asam eikosapentanoat (EPA), asam dokosaheksanoat (DHA) ikan dan status gizi dengan prestasi belajar siswa. Jurnal Gizi Indonesia (The Indonesian Journal of Nutrition), 1(2), 15-25. https://doi.org/10.14710/jgi.1.2 